\title{
10. SEDIMENTARY AND STRUCTURAL CHARACTERISTICS OF THE CRETACEOUS ALONG THE CÔTE D'IVOIRE-GHANA TRANSFORM MARGIN AND IN THE BENUE TROUGH: A COMPARISON ${ }^{1}$
}

\author{
Jean Benkhelil, ${ }^{2}$ Jean Mascle, ${ }^{3}$ and Michel Guiraud ${ }^{4}$
}

\begin{abstract}
The Côte d'Ivoire-Ghana Marginal Ridge (CIGMR) and the Benue Trough were formed during the Early Cretaceous under similar tectonic conditions and continental sedimentary environments. Early stages of sedimentary infilling are characterized by the deposition of subaerial, lacustrine, deltaic, and transitional marine sediments, successively, from the Late Jurassic to the Albian. Intracontinental transcurrent faulting, occurring in the Aptian-Albian, was superimposed on earlier rifting structures, resulting in pull-apart sub-basins. The extensional-transtensional tectonics caused unstable conditions during the sedimentation, resulting in syn-sedimentary deformations such as water-escape structures, listric normal faults, slumps, and intraformational conglomerates. From the Albian to the end of the Cretaceous, the two domains were under marine conditions, and there was deposition of shallow-water carbonates of fine terrigenous sediments.

Compressional movements occurred in the late Albian-Cenomanian along the CIGMR and during the Santonian in the Lower Benue Trough resulting in intense deformations in both domains, with folding, cleavage, and shearing. Thermal events, partly related to the compressional phase, were recorded in the sediments of the two basins, including hydrothermal activity and low-grade metamorphic crystallizations.

After the compressional event, the two basins have different evolutions; the CIGMR became a passive margin, with open marine sedimentation, while the Benue Trough was almost completely uplifted when a second compressional phase occurred in the Upper Benue Trough at the Cretaceous/Tertiary boundary.
\end{abstract}

\section{INTRODUCTION}

During the breakup of western Gondwanaland, the American and African continents did not split along their entire lengths simultaneously. The last areas to be in contact around the South Atlantic were the West African and the Brazilian cratons during the Early Cretaceous.

The Equatorial Atlantic formed as a series of large pull-apart basins, bounded by both rifted and transform segments (Rabinowitz and Labrecque, 1979; Fig. 1). The deep Côte d'Ivoire-Ghana Basin and its southern border, the future Côte d'Ivoire-Ghana Marginal Ridge (CIGMR), is one such basin (Fig. 1). Farther east, within the reentrance of the West African coast, a large intracontinental basin, the Benue Trough, formed during the Aptian-Albian as a consequence of the general transtensional regime occurring in the region.

Geophysical studies (Basile et al., 1993), a deep dive survey (Mascle et al., 1993), and Ocean Drilling Program (ODP) Leg 159 drilling (Mascle, Lohmann, Clift, et al., 1996) have now clearly established that the CIGMR is a thick clastic wedge that has been subjected to the combined effects of extension and wrench tectonics between the separating African and South American continents.

The Benue Trough of Nigeria (Fig. 1) is a northeast-trending intracontinental basin $>800 \mathrm{~km}$ long that connects to the east with the African intracontinental rift system through the Bornu basin (Fig. 2). Southward, it reaches the continental margin, where it is concealed under the thick sedimentary pile of the Niger delta.

The Benue Trough may be subdivided into three main structural and sedimentary domains (the Lower, Middle and Upper Benue); each domain has recorded a separate sedimentary and structural history (Benkhelil, 1988). The Benue Trough includes pull-apart subbasins where rifting and wrenching were active concurrently

${ }^{1}$ Mascle, J., Lohmann, G.P., and Moullade, M. (Eds.), 1998. Proc. ODP, Sci. Results, 159: College Station, TX (Ocean Drilling Program).

${ }^{2}$ URA-CNRS n ${ }^{\circ} 715$, Sédimentologie et Géochimie Marines, Université de Perpignan, 66860 Perpignan, France. jb@univ-perp.fr

${ }^{3}$ UMR Géosciences Azur, BP n48, 06230 Villefranche-sur-Mer, France.

${ }^{4} \mathrm{UMR} \mathrm{n}^{\circ}$ 5561: Paléontologie Analytique et Géologie Sédimentaire, Centre des Sciences de la Terre, Université de Bourgogne, 6 Bd Gabriel, 21000 Dijon, France.

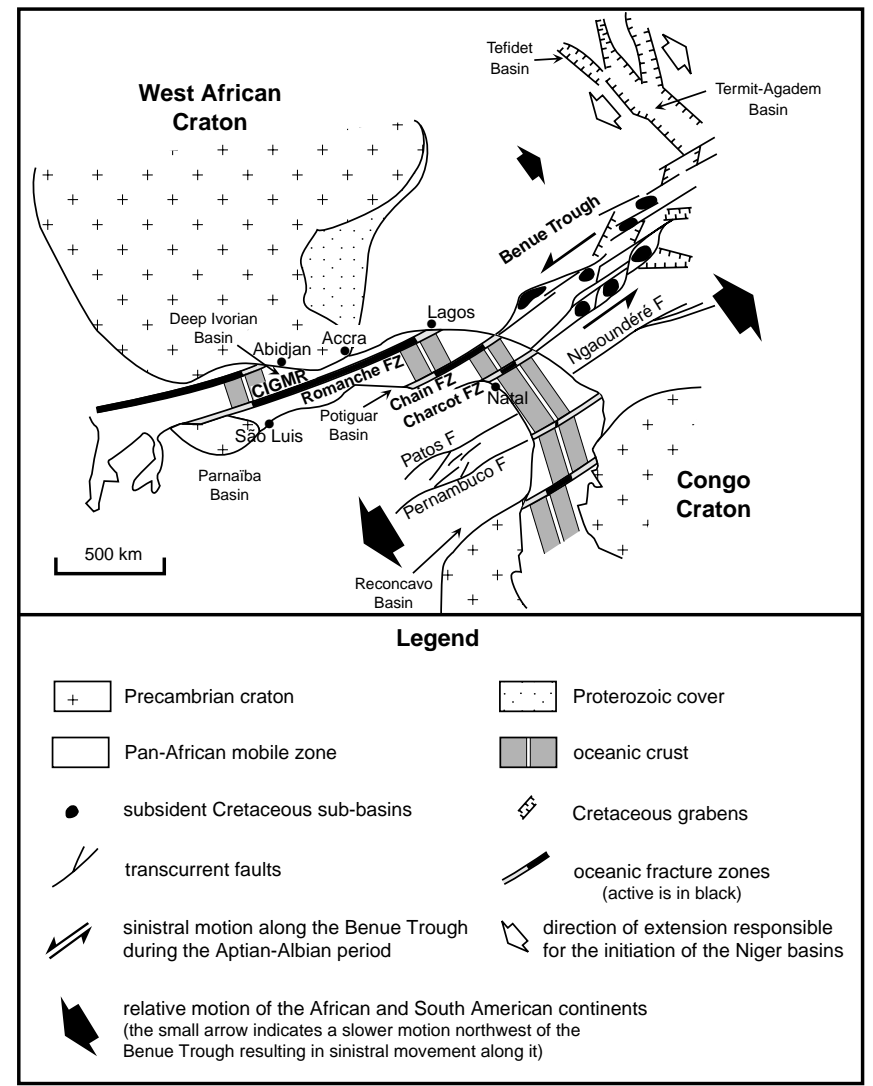

Figure 1. Reconstruction of the Gulf of Guinea area during the Albian, showing the CIGMR and the Benue Trough. 


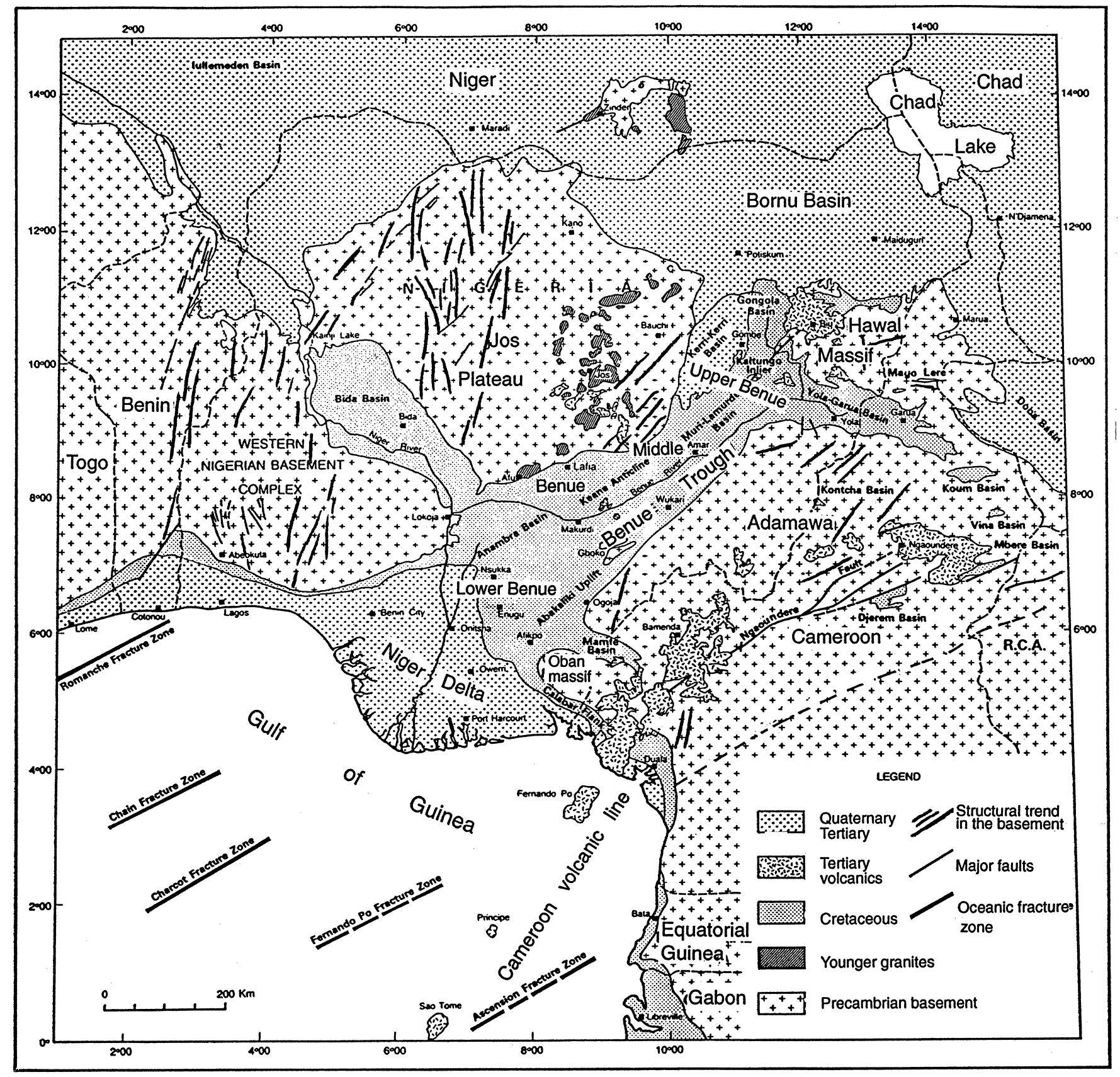

Figure 2. Geological sketch map of the Benue Trough and surroundings. Offshore, the traces of the Equatorial Fracture Zones are indicated.

(Benkhelil, 1988; Guiraud, 1993). The initiation and evolution of this large-scale intracontinental system is related to the opening of the Equatorial Atlantic during the Early Cretaceous (Mascle, 1976; Benkhelil and Robineau, 1983; Guiraud and Maurin, 1991, 1993). Structural patterns result from various depositional environments, and from separate and successive tectonic and thermal regimes, as indicated in Figure 3.

\section{THE COTE D'IVOIRE-GHANA TRANSFORM MARGIN AND THE BENUE TROUGH: MAIN SEDIMENTARY AND STRUCTURAL CHARACTERISTICS}

\section{Basement}

Within the equatorial area, the breakup of Gondwana mainly affected the old Precambrian West African craton, which was partly re- juvenated during the Pan-African orogeny (-550 Ma; McCurry, 1971). Thick mylonitic zones cut across this basement and are believed to have helped to localize the emplacement of the future Equatorial Fracture Zones (Fail et al., 1970; Benkhelil and Robineau, 1983; Maurin and Guiraud, 1993; Figs. 1, 2).

\section{Sedimentary Basins}

\section{The Côte d'Ivoire-Ghana Domain}

The oldest rocks that bottom the Côte d'Ivoire-Ghana domain are sandstones and marine shales ranging from the Silurian to the lower Carboniferous and are located in the Keta basin along the Ghana coast (Kjemperud et al., 1992; Tucker, 1992). After an early stage of rifting marked by volcanic activity, including doleritic sills during the Triassic and the Middle Jurassic, extensional stresses lead to the formation of basins rapidly filled by continental sediments (Guiraud 


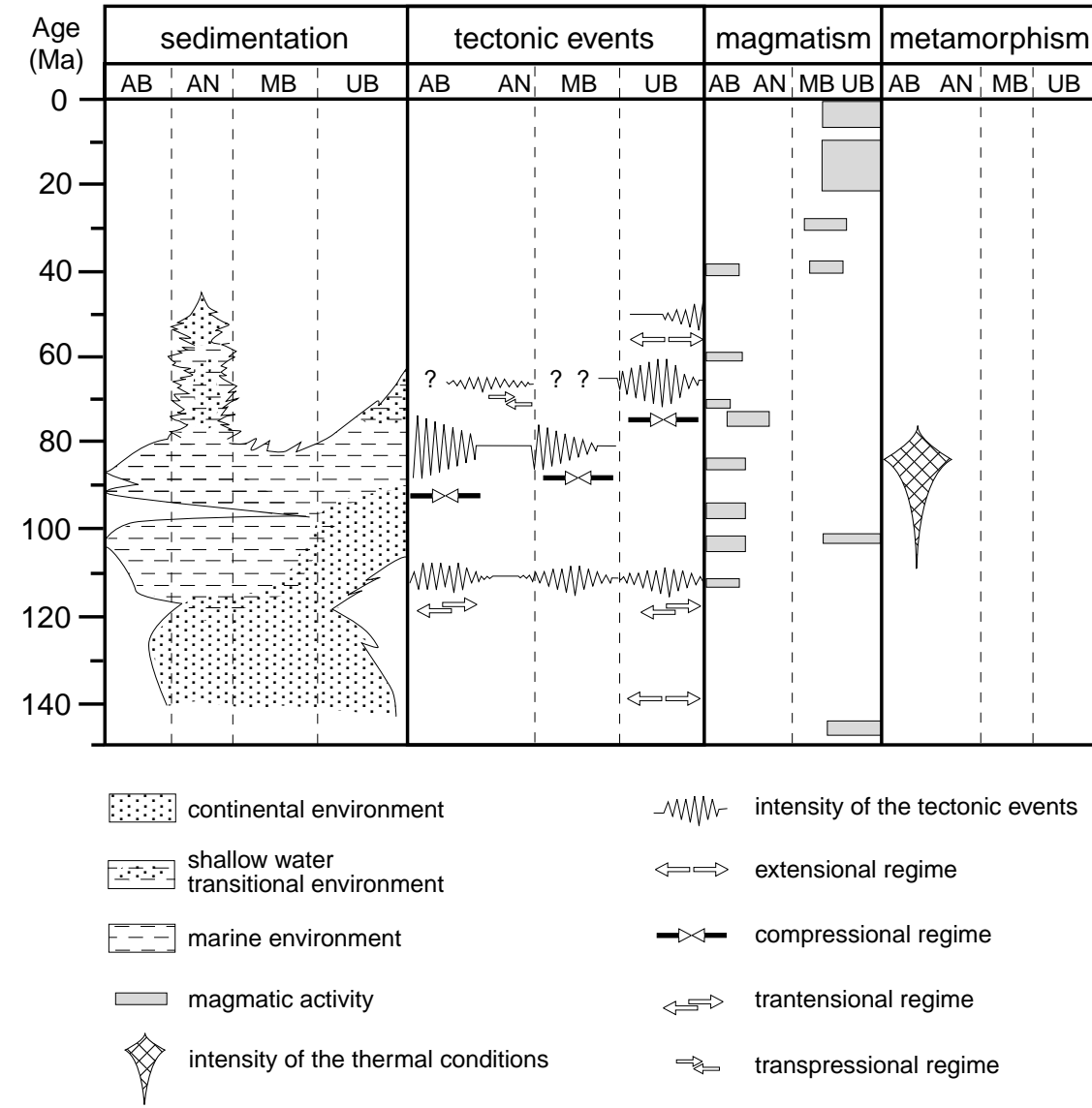

Figure 3. Sequence of geological events in the Benue Trough since the Jurassic. $\mathrm{AB}=$ Abakaliki Anticlinorium, $\mathrm{AN}=$ Anambra Syncline, $\mathrm{MB}=$ Middle Benue, $\mathrm{UB}=$ Upper Benue. and Maurin, 1991). Reconstructions of the Equatorial Atlantic and the surrounding continental disruption (Sibuet and Mascle, 1978) indicate that a broad rifted basin formed in the area presently occupied by the Côte d'Ivoire Margin and the Deep Ivorian Basin (Caprona, 1992; Mascle et al., 1993; Masse, 1993).

During early infilling in the Early Cretaceous, sedimentation was continental (subaerial, lacustrine, deltaic), and progressively evolving into transitional marine and then open marine deposition in a deepening basin. This has been clearly demonstrated by deep diving observations and sampling (Guiraud et al., 1997a; Benkhelil et al., 1996) and by Mascle, Lohmann, Clift, et al., (1996). The Albian is characterized by fine terrigenous sediments that become carbonates in the Turonian. A well-marked erosional unconformity forms a sharp boundary between syntransform tectonized siliciclastic sediments and overlying the Late upper Cretaceous deposits. The latter include periplatform carbonates in grain flow deposited in shallow water on the uplifted marginal ridge from the Turonian to Coniacian. After the late Campanian, a dramatic change in depositional environment, caused by a rapid subsidence of the marginal ridge, is marked by the cessation of clastic input. After a period of low-rate sedimentation, biosiliceous sediments were deposited on the ridge, while black shales occurred in the adjacent Deep Ivorian basin. The biosiliceous sedimentation is dominant during the early Cenozoic and replaced by a pelagic to hemipelagic sedimentation during the Neogene.

\section{The Benue Trough Domain}

The Côte d'Ivoire-Ghana Basin and the Benue Trough are 1000 $\mathrm{km}$ apart and separated by the Togo-Benin-Lagos Mesozoic-Cenozoic coastal basins (Martin, 1992).

Three main evolutionary phases characterize the Benue Trough as a whole; a northern basin started to form during the latest Jurassic in which fanglomerates and microconglomerates accumulated (Guiraud, 1993); a second rifting episode occurred from the Neocomian to the early Albian leading to the deposition of thick continental and lacustrine deposits in rapidly subsiding depocenters bounded by normal and transcurrent faults. In the Upper Benue Trough (Fig. 2), thick deltaic sediments were deposited during the Albian, while a marine transgression occurred in the southern domain. Finally, incipient half-grabens and wrench-induced structures were submitted to intense folding and faulting at $\approx 84 \mathrm{Ma}$ (the Santonian; Benkhelil, 1988; Guiraud, 1993).

The lithologies of the Aptian-Albian deposits are very similar in the Lower Benue Trough and along the CIGMR. Albian facies include, in both domains, finely laminated siltstones and claystones intercalated with fine-grained sandstones (Benkhelil, 1988; Guiraud et al., 1997). In the Benue Trough, three main episodes of magmatic activity occurred in the latest Jurassic-Albian, the Albian-Santonian and the Paleocene-Eocene (Baudin, 1991). In the Abakaliki domain, the magmatic activity includes intrusions and thin interbedded layers of ash and scattered occurrences of volcanic ashes in siltstones (Benkhelil, 1988).

\section{Aptian-Albian Sedimentary Instability}

In both domains, the Aptian-Albian sedimentary successions show clear evidence of sedimentary instability, including waterescape structures, sand pipes, convolute laminations, slumps, and listric normal faults (Benkhelil et al., 1996; Guiraud et al., 1997b). In the Benue Trough, slump structures are particularly abundant near major shear zones running along the Abakaliki uplift (Fig. 2). Intraformational conglomerates, well developed in carbonate siltstones, result from gravitational collapse perhaps triggered by earthquakes. 


\section{Tectonic Records}

\section{The CIGMR}

Structural features related to extensional tectonics are clearly portrayed on seismic profiles across the Deep Ivorian Basin (DIB). The basin exhibits a typical rifted marginal structure overall, including half-grabens and rotated blocks (Basile et al., 1993); its southern border, the CIGMR, is itself interpreted as a tectonically uplifted part of this rifted basin (Mascle, Lohmann, Clift, et al., 1996). Typical microdeformations generated as consequences of extensional events were recorded within the sedimentary section. They clearly differ from the gravity-induced soft sediment deformations previously described. Among them we observe folds resulting from shear parallel to bedding apparently induced by progressive sliding of an overlying body (Benkhelil et al., Chap. 3, this volume). Where the sediments were still water rich, the folds generated were similar displaying axial planes parallel to bedding (Pl. 1, Fig. 1). A rough axial plane cleavage, emphasized by alignment of micas, also occurs locally (Pl. 1, Fig. 2; Fig. 4). In more indurated sediments, almost brittle and plastic microstructures may develop concurrently (Benkhelil et al., Chap 3, this volume).

The overall extensional structural pattern is indicative of an Early Cretaceous rifting phase. Microstructures in samples are indicative of extension and consist almost exclusively of normal faults; they appear as sets of conjugate fractures bounding horst and graben microstructures, often of limited extent in the strata and commonly mineralized (Pl. 1, Fig. 3). Arguments for formation earlier than general tilting of the strata are established within Leg 159 data (Benkhelil et al., Chap. 3, this volume).

Within the CIGMR, compressional deformation relates to an early stage of margin evolution, when the sediments that had previously been deposited in extensional basins were submitted to shear stresses as a consequence of transform activity. The resulting structures are of two types: large-scale folds, only recognized near the top of the marginal ridge (Basile et al., 1993; Benkhelil et al., 1996), microfolds, and associated reverse faults, which are clearly visible in Albian sediments (Benkhelil et al., Chap. 2, this volume). A cleavage is again well developed in claystones and siltstones and is characterized by closely spaced fractures in sandstones. This cleavage is chiefly detected in the lower part of the sedimentary pile (Benkhelil et al., 1996). Lens-shaped bodies bounded by slickensided fault planes and plunging drag folds, observed along the southern slope of the CIGMR (Benkhelil et al., 1996), are considered good indicators of strike-slip faulting. Shear zones have also been observed in Albian sediments from Sites 960 to 962 . They consist of vertical shear planes

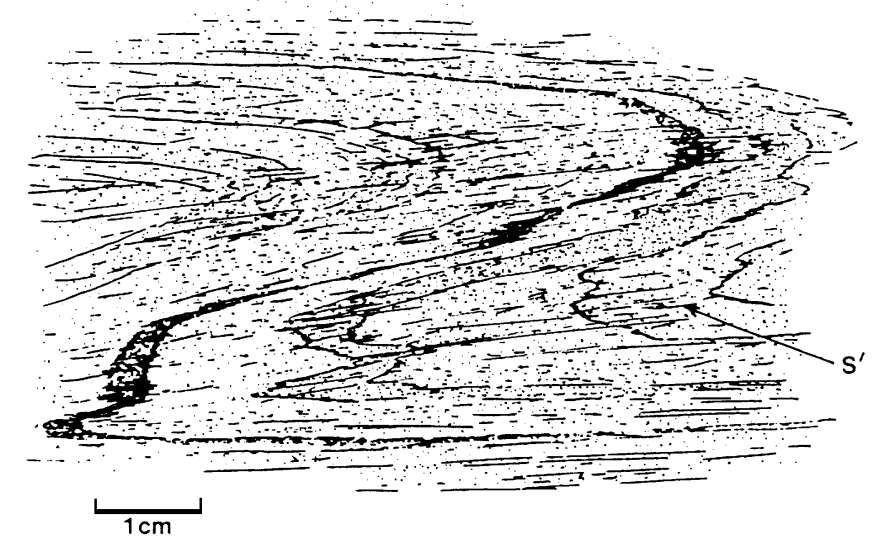

Figure 4. Slump fold in a water-rich calcareous siltstone showing associated axial plane cleavage(s) (Abakaliki Uplift, Benue Trough). filled with crushed material (Pl. 1, Fig. 5); these zones separate blocks themselves highly deformed by microfolding and incipient crenulation. The geometry of microfolding as well as the microstructure of the crenulation indicate that this deformational event occurred in soft sediment.

\section{The Benue Trough}

Evidence of extensional movements are widespread all along the Benue Trough. Normal faults are recorded at several scales, from the large faults several hundred meters long in the Late Jurassic-Early Cretaceous continental sandstones of the Upper Benue Trough (Guiraud, 1993) to small-scale sets of conjugate fractures in Albian siltstones and claystones of the Lower Benue Trough (Benkhelil, 1988; Pl. 1, Fig. 4).

In this area, and especially in the Abakaliki domain (Fig. 2), compressional structures such as the one usually found in mountain chains are observed. In fact, the area can be interpreted as a large "anticlinorium" characterized by folding and associated cleavage, reverse faulting, and transcurrent shearing (Benkhelil, 1988). Cleavage is particularly well expressed in fine-grained lithologies such as claystones, siltstones, and fine-grained sandstones that constitute most of the thick Albian section (Fig. 5).

Large shear zones, including drag folds, crenulation, and other small-scale microstructures are also well developed (Pl. 1, Fig. 6). In some areas, shear zones are strongly deformed and contain mylonites which display significant recrystallization. As is the case in the CIGMR, parts of the structural deformation seen in the Abakaliki domain were clearly generated in only partially indurated sediments.

We believe, but cannot demonstrate, that most of the sedimentary structural features of the CIGMR and those of the Benue Trough, developed as a consequence of basement-seated transcurrent faults; these deep-seated lineaments are displayed within the Aptian and Albian sedimentary cover of the two areas as anastomosed shear zones,

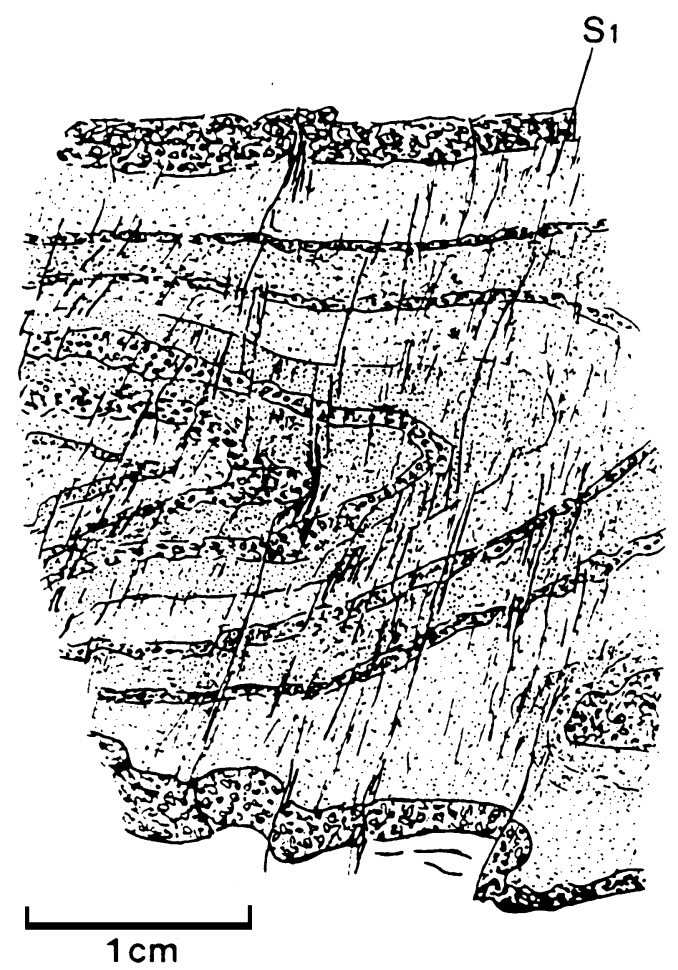

Figure 5. Slump fold in fine-grained sandstone (Albian Asu River Group), cut by a cleavage (S1) related to the Santonian compressional event (Abakaliki Uplift, Benue Trough). 
which gave rise to flower structures (Benkhelil, 1988; Guiraud, 1993; Benkhelil et al., Chap. 2, this volume).

\section{Thermal History}

The thermal histories of the CIGMR and the Benue Trough have several similarities resulting from an apparent abnormal geothermal gradient, itself generated by crustal thinning during a transtensive evolution.

In the Benue Trough, this tectonic episode is coeval with relatively important magmatic events (Baudin, 1991), which are unknown in the CIGMR. In both cases, the thermal gradient was strong enough to have been recorded in the sedimentary piles by mineral parageneses, indicating moderate temperatures. Mineral transformations are of two main types:

1. Chlorite-mica intergrowths developing exclusively in finegrained lithologies, such as siltstones and claystones. The structure and origin of such stacks have been described and discussed in Craig et al. (1982), and a pre-tectonic origin, controlled by diagenesis and low-grade metamorphism, appears most likely. The distribution of chlorite-mica stacks does not necessarily relate to the lithologic variations. For example, the first appearance of chlorite stacks in Hole 960A on the CIGMR is found at 357 meters below sea floor (mbsf), which correlates with the upper part of Unit V (late Albian), mainly made up of lacustrine claystones and siltstones. Well-developed stacks (Fig. 6A) have also been observed in samples from the lowermost part of the CIGMR retrieved during the Equanaute survey (Benkhelil et al., 1996).

In the Abakaliki domain, the distribution of chlorite-mica stacks appears restricted to the lower sections of thick shaly Albian sequences. In both domains, a close relationship between cleavage and stacked crystallization indicate clearly that these transformations formed prior to the compressional event (Fig. 6B).

An attempt at thermometric evaluation (Cathelineau and Nieva, 1985), based on both the Al(iv) content and the variation of octahe- dral occupancies (6-Alvi), was performed on chlorite-mica stacks from Abakaliki samples; this method indicates two distinct thermal events at $\sim 315^{\circ}-330^{\circ} \mathrm{C}$ and $\sim 190^{\circ}-240^{\circ} \mathrm{C}$ (Benkhelil, 1988).

2. A second type of mineral neoformation, clearly subsequent to the creation of chlorite-mica stacks, is seen in the sedimentary piles of the two areas. It consists of recrystallization of fine mica flakes, especially in clayey rocks and sometimes in siltstones. On the CIGMR, these recrystallizations are only detected within the deeper parts of Leg 159 sites (i.e., in Unit V); they are, however, widespread and quite common in samples collected along the slope during the Equanaute survey (Benkhelil et al., 1996).

In the Benue area, these recrystallizations affect the entire claystone and siltstone sequence, which constitutes the core of the Abakaliki "anticlinorium." The mineral paragenesis is, however, not well characterized and no typical mineral index of low-grade metamorphism can been recognized. As indicated by Winkler (1976), the appearance of such index minerals may be more related to the chemical composition of the sediment than to an increase in temperature. In fact, many sedimentary rocks do not show clear mineralogical changes at the diagenesis-anchimetamorphism boundary; this seems to be particularly valid for lithologies that contain quartz, chlorite, and illites as in the two studied areas. A better crystallinity of micas is, however, observed, and appears to be well recorded in a metamorphic aureole around the Abakaliki uplift (Benkhelil, 1988).

The most prominent evidence of metamorphic mineral neoformation is provided by recrystallization seen along the cleavage planes on the Equanaute samples from the CIGMR southern slope. These samples exhibit a distinct cleavage with clearly aligned mica flakes (Fig. $6 \mathrm{~A})$. In the Abakaliki anticlinorium, fine-grained rocks have even been turned into slates, and syntectonic micas are also aligned along the cleavage planes.

Final evidence of metamorphic transformations comes from the presence of pressure shadows seen around rigid bodies, usually iron oxides (Fig. 6B). These pressure shadows have been identified within several Leg 159 samples (Samples 159-960A-43R-1, 20-23 cm, and
A

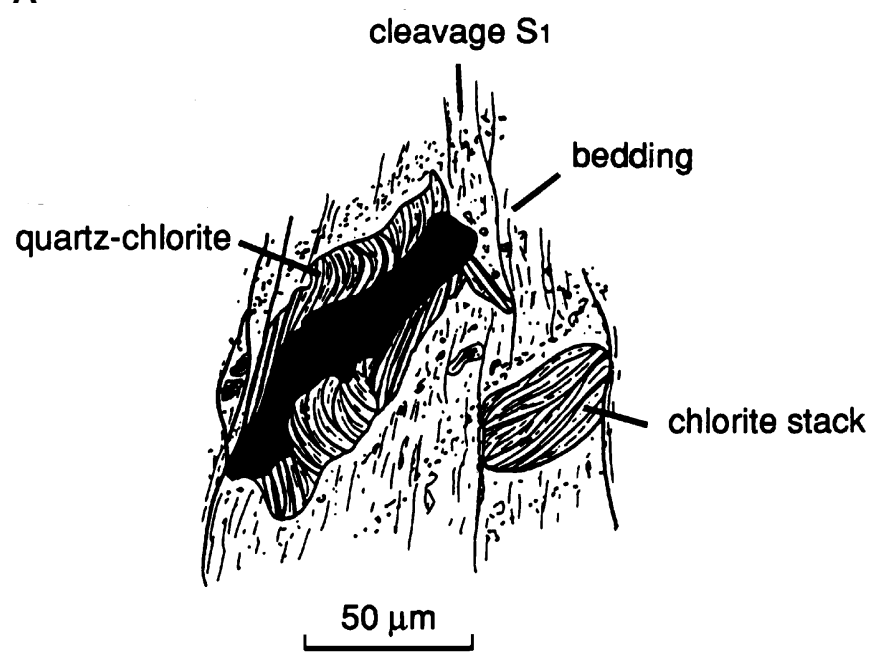

B
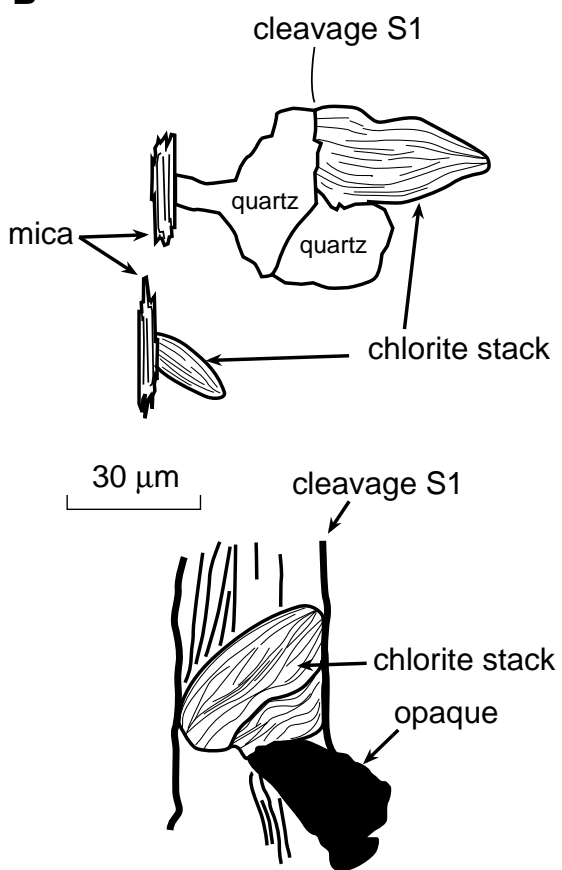

Figure 6. Chlorite-mica stacks and new-formed minerals (Albian siltstones of the Benue Trough). A. Relationships between the new-formed micas related to the cleavage and the chlorite stacks in Early Cretaceous siltstones of the CIGMR. B. Crystallization of quartz/chlorite around a rigid body. The minerals, slightly sigmoidal, are parallel to cleavage. A chlorite/mica stack is clearly cut by the cleavage. 
159-960A-55R-1, 138-140 cm) and in samples from the CIGMR slope dives, as well as within the metamorphic area of the Abakaliki domain.

Finally, hydrothermal minerals are common in both areas, occurring as infilling of fractures or associated with breccias. Within the CIGMR, the mineral parageneses resulting from these events include calcite, kaolinite, quartz, pyrite, barite, and siderite. Fluid-inclusion studies on quartz veins from the bottom of Hole 960A have provided two temperatures of vein formation: $150^{\circ}$ and $350^{\circ} \mathrm{C}$ (Lespinasse et al., Chap. 6, this volume). In the Benue Trough, hydrothermal activities are particularly well illustrated by an association including sphalerite, galena, marcasite, quartz, and siderite. On the basis of fluid-inclusion observations performed on sphalerite, quartz, and traceelement contents (Olade and Morton, 1985), relatively low temperatures $\left(100^{\circ}-175^{\circ} \mathrm{C}\right)$ have been suggested for the formation of this mineralization.

\section{CONCLUSION}

The Côte d'Ivoire-Ghana Margin and the Benue Trough display several similar sedimentary and tectonic features. In both areas, the initial stages of rifting (Early Cretaceous) are comparable, with grabens filled by continental deposits and formed under extension followed by transtensional movements due to intracontinental wrenching. Marine sediments were deposited during the Albian under unstable tectonic environment resulting in numerous soft sediment deformation related to the activity of fault zones. A compressional tectonic phase was recorded in the two basins at different times; the late Albian-Cenomanian along the CIGMR and the Santonian in the Lower Benue Trough. In both cases, the folding, cleavage, and fracturing occurred with shearing attributed to transpression along major transcurrent fault zones. The thermal regimes including an hydrothermal activity and low-grade metamorphic recrystallization were quite similar both occurring before or during the tectonic phase of compression. The similarities between these domains may be explained by the geological conditions prevailing during the early stages of formation of these intracontinental wrench-controlled basins. Important differences started to appear during the Late Cretaceous when the newly created Côte d'Ivoire-Ghana Margin, which is prominent in the Côte d'Ivoire-Ghana Marginal Ridge adjacent to the oceanic lithosphere, began to subside as a consequence of progressive cooling, whereas the Benue domain was submitted to restricted marine to continental sedimentary conditions, ending in the Maastrichtian by a general emergence of the domain.

\section{ACKNOWLEDGMENTS}

This manuscript is contribution number 118 of Geosciences-Azur (UMR-CNRS-6526) and a contribution of LSGM (URA-CNRS-715).

\section{REFERENCES}

Basile, C., Mascle, J., Popoff, M., Bouillin, J.P., and Mascle, G., 1993. The Côte d'Ivoire-Ghana transform margin: a marginal ridge structure deduced from seismic data. Tectonophysics, 222:1-19.

Baudin, P., 1991. Le magmatisme mésozoïque à cénozoïque du fossé de la Bénoué (Nigéria): géochronologie, pétrogénèse, cadre géodynamique [Thèse doctorat]. Univ. Aix-Marseille III.

Benkhelil, J., 1988. Structure et évolution géodynamique du bassin intracontinental de la Bénoué, (Nigéria) [Thèse d'Etat]. Univ. Nice. and Bull. Cent. Rech. Explor. Prod. Elf Aquitaine, 12: 29-128.

Benkhelil, J., Guiraud, M., Mascle, J., Basile, C., Bouillin, J.-P., Mascle G., and Cousin M., 1996. Enregistrement structural du coulissage Afrique/ Brésil au sein des sédiments crétacés de la marge transformante de Côte d'Ivoire-Ghana. C. R. Acad. Sci. Ser. 2, 323: 73-80.
Benkhelil, J., and Robineau, B., 1983. Le fossé de la Bénoué est-il un rift? In Popoff, M., and Tiercelin, J.J. (Eds.), Rifts et fossés anciens. Bull. Centres Rech. Explor.-Prod. Elf-Aquitaine, 7:315-21.

Cathelineau, M., and Nieva, D., 1985. A chlorite solid solution geothermometer: the Loz Azufres (Mexico) geothermal system. Contrib. Mineral. Petrol., 91:235-244.

Craig, J., Fitches, W.R., and Maltman, A.J., 1982. Chlorite-mica stacks in low-strain rocks from central Wales. Geol. Mag., 119:243-256.

de Caprona, G.C., 1992. The continental margin of Western Côte d'Ivoire: structural framework inherited from intra-continental shearing. Geol. Inst., A69.

Fail, J.P., Montadert, L., Delteil, J.R., Valery, P., Patriat, P., and Schlich, R., 1970. Prolongation des zones de fractures de l'océan Atlantique dans le golfe de Guinée. Earth Planet. Sci. Lett., 7:413-419.

Guiraud, M., 1993. Late Jurassic-Early Cretaceous rifting and Late Cretaceous transpressional inversion in the Upper Benue basin (NE Nigeria). Bull. Cent. Rech. Explor-Prod. Elf-Aquitaine, 17:371-383.

Guiraud, M., Benkhelil, J., Mascle, J., Basile, C., Mascle, G., Bouillin, J.P., and Cousin, M., 1997b. Syn-rift to syn-transform deformation: evidences from deep sea dives along the Côte d'Ivoire-Ghana transform margin. Geo-Mar. Lett., Spec. Iss.

Guiraud, M., Mascle, J., Basile, C., Benkhelil, J., Durand, M., Mascle G., and the Equanaute Team, 1997a. The Early Cretaceous sedimentary environment of the Ivory Coast-Ghana margin from deep dives data. GeoMar. Lett. Spec. Iss.

Guiraud, R., and Maurin J.C., 1991. Le rifting en Afrique au Crétacé inférieur: synthèse structurale, mise en évidence de deux phases dans la genèse des bassins, relations avec les ouvertures océaniques péri-africaines. Bull. Soc. Geol. Fr., 162: 811-823.

1993. Cretaceous rifting and basin inversion in Central Africa. In Thorweihe, U., and Schandelmeier, H. (Eds.), Geoscientific Research in Northeast Africa: Rotterdam (A.A. Balkema), 203-206.

Kjemperud, A., Agbesinyale, W., Agdestein, T., Gustafsson, and Yükler, A., 1992. Tectono-stratigraphic history of the Keta Basin, Ghana with emphasis on late erosional episodes. Geol. Afr.: Coll. Geol. Libreville, Rec. Communic., 55-69.

Martin, G., 1982. Geologie des Küstengebietes von Nordwest-Afrika südlich der Sahara. Giess. Geol. Schrift. 30.

Mascle, J., 1976. Le golfe de Guinée: un exemple d'évolution de marge atlantique en cisaillement. Mem. Soc. Geol. Fr., 128.

Mascle, J., Guiraud, M., Benkhelil, J., Bouillin, J.-P., Cousin, M., and Mascle, G., 1993. La marge transformante de Côte-d'Ivoire-Ghana: premiers résultats de la campagne Equanaute (Juin 1992). C. R. Acad. Sci. Ser. 2, 308:997-1004.

Mascle, J., Lohmann, G.P., Clift, P.D., et al., 1996. Proc. ODP, Init. Repts., 159: College Station, TX (Ocean Drilling Program).

Masse, J.P., 1993. Early Aptian (114-122 Ma). In Dercourt, J., Ricou, L.E., and Vrielynck, B. (Eds.), Atlas Tethys Paleoenvironmental Maps: Paris (Gauthier-Villar), 135-152.

Maurin, J.C., and Guiraud, R., 1993. Basement control in the development of the Early Cretaceous West and Central African Rift System. Tectonophysics, 228:81-95.

McCurry, P., 1971. Pan-African orogeny in Northern Nigeria. Geol. Soc. Am. Bull., 82:3251-3262.

Olade, M.A., and Morton, R.D., 1985. Origin of lead-zinc mineralization in the southern Benue Trough, Nigeria-Fluid inclusion and trace element studies. Mineral. Depos., 20:76-80.

Rabinowitz, P.D., and LaBrecque, J.L., 1979. The Mesozoic South Atlantic Ocean and evolution of its continental margins. J. Geophys. Res., 84:5973-6002.

Sibuet, J.-C., and Mascle, J., 1978. Plate kinematic implications of Equatorial Fracture Zone trends. J. Geophys. Res., 83:3401-3421.

Tucker, W., 1992. Aspects of the Tano Basin stratigraphy revealed by recent drilling in Ghana. Geol. Afr.: Coll. Geol. Libreville, Rec. Communic., 153-159.

Winkler, H.G.F., 1976. Petrogenesis of Metamorphic Rocks: New York (Springer-Verlag).

Date of initial receipt: 20 September 1996

Date of acceptance: 17 February 1997

Ms 159SR-007 


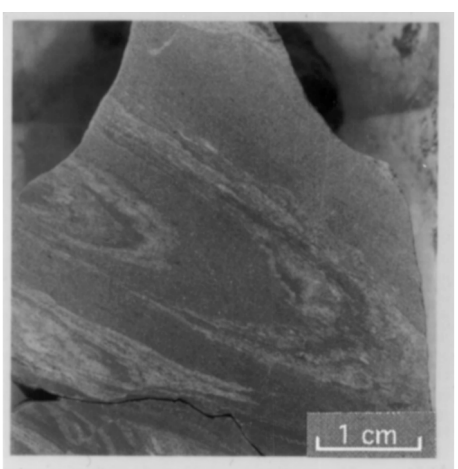

1

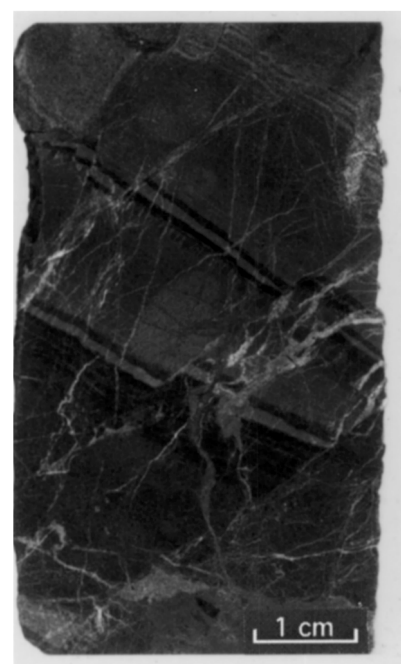

3

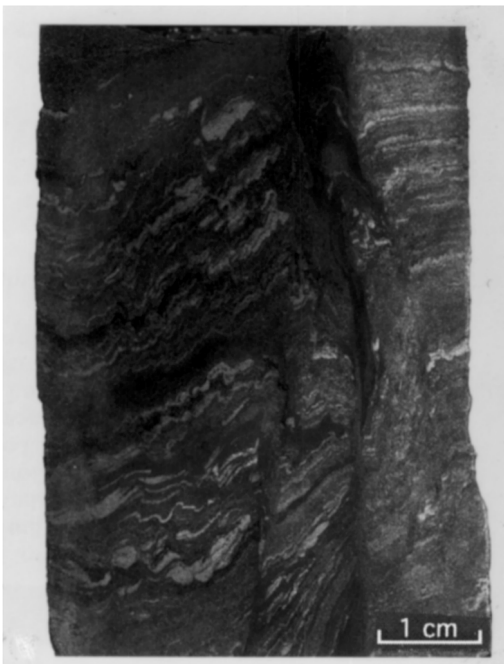

5

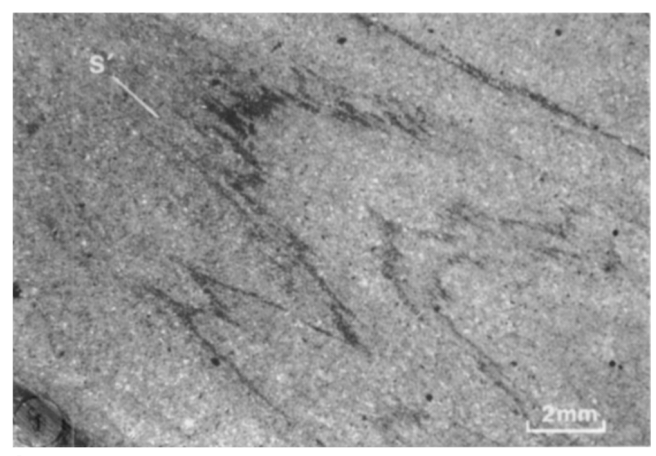

2

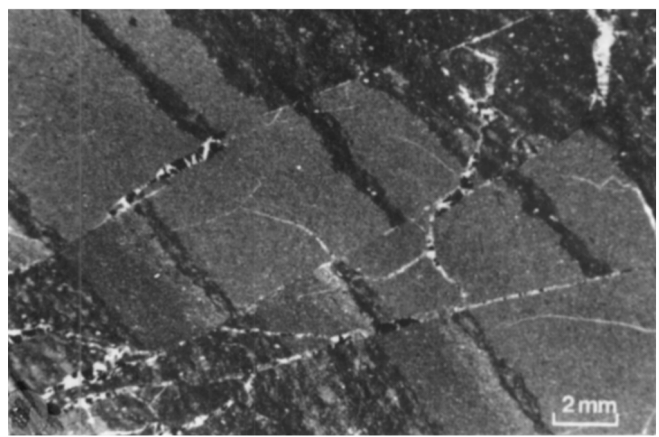

4

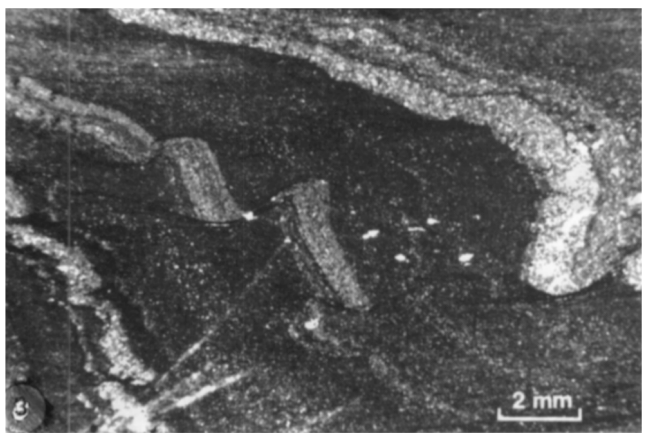

6

Plate 1. Comparison of structures along the CIGMR (Figs. 1,3,5) and in the Benue Trough (Figs. 2, 4, 6). 1. Isoclinal slump fold with a sheared limb in siltstones and claystones of Unit V (Sample 159-961B-18R-1, 0-10 cm). 2. Slump fold siltstone of the Abakaliki uplift (Albian Asu River Group) with an associated early cleavage. 3. Conjugate normal faults formed prior to tilting and veining in laminated dolomitic siltstone and claystone (Sample 159-962D-6R-CC, 2$11 \mathrm{~cm}$ ). 4. Tilted normal faults filled with calcite in calcareous siltstone of the Albian series (Abakaliki Uplift). 5. Shear zone characterized by crenulation and associated microfolding in lenticular bedded siltstone (Sample 159-961B-13R-1, 135-137 cm). 6. Shear planes truncating and offsetting sandy layer in Albian siltstones (Abakaliki Uplift). 